\title{
Instilling Values Character Education Through Playing Role Model in Learning History
}

\author{
Anzar Abdullah \\ Universitas Pejuang Republik Indonesia \\ Makassar, Indonesia \\ anzarabdullah91@yahoo.co.id
}

\begin{abstract}
This paper aims to describe the history of the efforts of teachers in instilling the values of character education through learning model "role playing" in school. Efforts were made so that the values of character education integrated into history courses through the learning model "role playing". In addition, the need to identify a suitable historical material applied through learning model "role playing." This paper is expected to contribute ideas to the history teacher, about the learning model that can be used as a reference in instilling the values of character education and awareness of history to students.
\end{abstract}

Keywords: Instilling the value of character, Model Role Playing, Teaching History

\section{INTRODUCTION}

Concern for knowledge exaggerated and used as indicators of educational success, has led educational neglect other dimensions of human potential, such as aspects of values, attitudes, manners, ability to coexist with all elements of the difference, the love of the homeland and the nation, respect for the hero, and the values of heritage. Long tradition, rooted in the test as a tool to determine the amount of knowledge a person has, led to another dimension mentioned earlier, and difficult to measure with tests to be ignored. Various statutes and efforts to restore the function of education to develop the overall potential of students to be hindered in their realization. Education and teaching of history should Participate inculcate and develop human potential learners, that "in addition to intellectual potential, human beings have emotional potential, the potential to communicate through symbols, the potential of culture, the potential interest, the potential rewards, the potential for cooperation, creative potential, and the potential for self-actualization. In this case education history can be the inspiration driving force in the effort to build character (nation and character building). The aims in this researches are to know why learning model "role playing" very important to be applied in an effort to instill the values of character education in the subjects of history in school and to instill the values of character education through the model "role playing" in the subject of history in school.

\section{ASSESSMENT THEORY}

"Role playing" is a model of learning that comes from individual and social dimensions of education. This model can help each learner to find personal meaning in their social world, and help solve a personal dilemma with the help of a social group. In the social dimension of this model easier for people to work together in analyzing social circumstances, in particular the relationship between the human [1]. Model "role playing" in learning to develop politeness, instilling democratic values, social values in the face of every problem learners. This model, according [2] in the group of social learning model of values, which is to bid in the face of every issue of personal and interpersonal, and social activities.

"Role Playing" also called socio dramas or play the role performed by the students about the situation, which is very important for the development of cognitive, social, and emotional learners [3], [4]. Model "role playing" in the teaching of history that has been planned properly, can instill understanding the role of others (historical figures) in the context of the lives of people, such as the value of responsibility, the value of teamwork, the value of unity, values of caring, respect differences, and learning takes decisions in labor relations group [5], [6], [7]. "Role playing" is acting on specific behavior of people in a position to distinguish their respective roles within an organization or group in the community [8], [9]. So the model of "role playing" or role play is a way or a way to portray how people behave a certain (historical figures) in a position to distinguish the role of each [10], [11]. In other words, the learning model "role playing" is a learning model that is set by teachers by engaging learners in the play attitude, behavior, character of the hero in that role in playing a part In history within the context of events [12], [10].. In the learning model "role playing", learners are given the opportunity to develop the imagination in playing a character, and get reviews from teachers, so that learners can appreciate the properties of the example of the hero [13], [14],[15], [16]. Meanwhile, according to [17] "role playing" or role play is learning model as part of the simulation are directed to creativity historical events, creativity actual events, or events that may arise in the future. In the editorial or less the same, [18] stating the, that the "role playing" is acting in accordance with pre-defined role for a specific purpose, 
such as reviving the historical atmosphere, for example, reveal the struggle of the heroes of independence, or disclose the possibility for state will come. Of these references this can be said of "role playing" as a model of teaching history is to focus on themes or social issues, such as history, insurrection, upheaval, and the struggle for the independence movement [19], [20]. "Role playing" emphasizes the role of the learners in a game or an event. Through this role play, students can experience other situations through role play, so that students will have the experience of the identity of the character of those who played [21].

\section{a. Objectives Learning Model Role Playing}

From the aspect of purpose, model "role playing" according [18] and [22], suggests that the goal of "role playing" in history among other things: (1) to motivate feelings of learners, (2) to clarify the historical or contemporary situation, where in which there are conflicts, emotions, differences, prejudices, problems caused differences of race, age, religion, nationalism, and ethnic backgrounds, (3) to create awareness of differences in the pattern of view, and consequently, the sensitivity or concern for the award each other's, teach the values embodied in human relations [23], [24].

b. Learning strategies

Learning strategy role playing, with regard to two things: (1) strategy of drafting the text to be played, and (2) learning strategies staging [25], [26], [27].

Play a role in learning is an effort of teachers to discuss problems in the lessons through demonstration or staging, the steps of problem identification, analysis, characterization, and discussion [28], [29], [30], [31]. For this purpose, a number of students acting as an actor, and the other as an observer. An actor should be able to live up to the roles they play. Through role, learners interact with other people who also take the role of certain correspond to the selected theme. Roles must be taken from the real life stories in history (not imaginative).

\section{METHOD}

A. Participants of the study

Participants of the study were high school in Makassar who were taking a capstone secondary teaching methods course with a sustained service-learning component (i.e., coaching an after school soccer program). The course was specifically designed to prepare pre-service teachers to become history education teachers and coaches in the public school. Those taking the course in the fall of 2015 and 2016 were in control group $(\mathrm{N}=40)$, and the other students who took the course in the fall of 2015 and spring 2016 participated in the role-play intervention $(\mathrm{N}=42)$. A Subset of 26 of the 42 intervention group student (15 males and 11 females) participated in the specific role-play activities and responded to both of the two questionnaires administrated in this study [32], [33]. The two investigators were lecturer in the same of Department of History Education (one from a Department of History of Education University of Pejuang of the Republic of Indonesia in Makassar, and the other from a Department of History Education State University of Makassar).

B. Role Play Activities.

The role-playing model in learning used in the study is by George and Fannie Shaft and consists of nine steps: (1) warm the atmosphere and motivate learners, (2) select cast (casting), (3) set up the observer, (4) setting up the stages of the scenario roles, (5) acting or performing in front of the class, (6) discussion and evaluation I, (7) characterization of the stage again, (8) discussion and evaluation II, (9) to share experiences and draw generalizations [34]. There are nine steps in role playing or playing a role, namely: (1) warm the atmosphere and motivate learners, (2) select cast (casting), (3) set up the observer, (4) setting up the stages of the scenario roles, (5) acting or performing in front of the class, (6) discussion and evaluation I, (7) characterization of the stage again, (8) discussion and evaluation II, (9) to share experiences and draw generalizations [35], [36], [37].

\section{RESULT AND DISCUSSION}

Characterization of this history, can be achieved internalization of values, attitudes, perceptions, skills in negotiating and negotiating, problem solving, and analysis of the subject matter. Impact accompaniment that can be achieved through role play are: (1) analysis of values and behaviors personal, (2) the skill in solving problems, (3) awareness, empathy for others, (4) an appreciation of the social values of the national culture, and (5) the ability to express opinions, negotiate, democracy and respect the opinions of others [2], [38], [39], [6].

During proses learning takes place, every characterization can train empathy, sympathy, hatred, anger, pleasure, and other appropriate roles played historical characters. The cast of "drifting" and "late" in the role it plays, while observers involve themselves emotionally and seek to identify feelings with feelings that churned and master characterization [39], [25], [11].

The learning model "role playing", is a model that is versatile, which can be applied in several learning objectives. Through "role playing", learners can improve their ability to recognize the feelings of others, the circumstances when the event occurred, and the ability to resolve the problems [40]. Therefore the focus model "role playing" is related to the feeling of exploration, exploratory behavior, criticism, creativity, leadership, values, and perceptions of, the development of skills in problem solving, and exploration of the subject matter [22], [12], [4].

The learning model "role playing" is interactive analytic. This model focuses on the attitudes and behavior of people in 
their natural environment (teachers and students) [41], [42]. Teachers and students are instrumental in interpreting the phenomenon, and to find the meaning of the game is played in learning. Learning outcomes illustrate that described in detail from the perspective of teachers and students [43], [24], [23]. This interactive learning describes the context of a historical phenomenon that never existed. Through interactive analytic methods descriptive, with a variation of a case study, learning "role playing" information very effectively in the effort to inculcate the values of character education in the nation's history in school subjects [44], [45].

How to design learning for planting Values? Learning is designed with attention to: (1) subject matter or material, or themes in the subjects of history that matches the model of role playing; (2) the involvement of learners when acting occurs, and after characterization happen, that the behavior of learners, teacher performance, and support facilities; (3) about the values of national character that can be internalized into the selflearners, namely: the value of responsibility, respect and courtesy, unyielding (firm establishment), love of homeland and nation, leadership and spirit of unity and self-sacrifice [46]. For example, the material on Independence Day Events Around Indonesia, Rengas Dengklok, Formulation Text Proclamation and Declaration of Independence Proclamation Indonesia August 17, 1945, and Maintaining the demands of Indonesian sovereignty in the Round Table Conference (RTC).

\section{CONCLUSION}

One model of learning that can be applied to embed or bequeath the value of the nation's character to students in the subjects of history is through the "role playing". Basic consideration is that this model can help learners to explore their feelings, attitudes, values and perceptions, skills development, building empathy and feelings of others. Therefore, the recommended model of this learning can be an example and a program conducted by the teacher to instill character values of the nation to the students as mandated by the Law on National Education System of the Republic of Indonesia No. 20 of 2003.

\section{REFERENCES}

[1] Joyce, Bruce, \& Weil, M, Models of Teaching: Model-Model Pengajaran, Edisi kedelapan. Yogyakarta: Pustaka Pelajar, 2011.

[2] Joice, Bruce, Weil, M., \& Calhoun E, Models of teaching ( $8^{\text {th }} e d$.). Boston, MA: Allyn \& Bacon, 2009.

[3] Snyder, F., Flay, B., Vuchinich, S., Acock, A., Washburn, I., Beets, M., $\& \mathrm{Li}, \mathrm{K}$, Impact of Social-emotional and Character development program on School-level indicators of academic achievement, absenteeism, and disciplinary outcomes; A matched-pair, clusters-randomized, controlled trial. Journal of Research on Educational Effectiveness, Vol. 3, pp. 26-55, 2010.

[4] Zain, Aswan, Strategi Belajar Mengajar. Jakarta: Rineka Cipta, 2006.

[5] Shofiatun, Pengaruh Bermain Peran (Role Playing) dalam Meningkatkan Pembelajaran Bahasa Inggris. Jurnal Pendidikan Bahasa Inggris, Vol. 33, pp.40-44, 2012.
[6] Retno, Dyah Palupi, Penerapan Strategi pembelajaran Bermain Peran (Role Playing) Untuk Meningkatkan Kemampuan Apresiasi Drama. Jurnal Sosiohumanika, Vol. IV, No.2, 2011.

[7] Arikunto, Suharsimi, Prosedur Penelitian. Jakarta: Rineka Cipta, 1998.

[8] Nawawi, Hadari, Psikologi Pendidikan Suatu Pendekatan Baru. Bandung: Remaja Rosdakarya, 1993.

[9] Kartini, Tien, Penggunaan Metode Role Playing Untuk meningkatkan Minat Siswa dalam Pembelajaran IPS di Kelas V SDN Cileunyi, Kec. Cileunyi Kab. Bandung. Jurnal Pendidikan Dasar, Vol. 8, pp. 12-15, 2007.

[10] Borris, Bodo Von, Methods and Aims of Teaching History in Europe A Report on Youth and History: Knowing Teaching and Learning History. National and International Perspectives (Eds. Stearns. PN. Seixas, P. Wineburg. S) New York: New York University Press, 2000.

[11] Powell, K. C, The of Concept of Self and Societal expectations in academic and career achievement. MPAEA Journal of Adult Education, Vol. 33, pp. 95-104, 2009.

[12] Zuhaerini, et.al. 1983. Ilmu Pendidikan Islam. Jakarta: Rineka Cipta.

[13] Wineburg, Making Historical Sense in Knowing Teaching and Learning History. National and International Perspectives. New York: New York University Press, 2000a.

[14] _ Historical Thinking and Other Unnatural Acts. Charting the Future of Teaching the Past Philadelphia. Temple University Press, 2000 b.

[15] Daniel, J; D. Andrea, M. \& Heck, R, Moral Development and Hawaiian Youths. Does Gender make a difference? Journal of Counseling \& Development, Vol. 74, pp.90-94, 1995.

[16] Hapidin, Metode Pembelajaran IPS. Jakarta: Depdikbud, 1995.

[17] Sanjaya, Pengembangan Kemampuan Berpikir Kritis Siswa dalam Pembelajaran IPS di Sekolah Dasar. Jurnal Historia, Vol. 11, No.2, pp. 20-22, 2007.

[18] Wahab. A, Abdul. Metode Pembelajaran Role Playing dan Pengajarnnya. Bandung: UPI Press, 2007.

[19] Sysoyep, P.V., Cultural Identity in the context of dialogue of cultures Tambov: Tambov State University, 2001.

[20] _.., Identity, Culture, and language Teaching : Iowa City, IA: Center for Russian, East European, and Eurasian Studies, 2002.

[21] Anderson, D.R., Character Education. Whois Responsible? Journal of Instructional psychology, Vol. 27, pp. 139-142, 2000.

[22] Horner, D., \& McGinley, K., Running simulation /games: A Step-bystep guide. In D. Crookall \& R. Oxford (eds.), Simulation, gaming and language teaching, pp. 33-45. New York: Newbury House Publishers, 1990.

[23] Goodwin, R., Costa, P. \& Adonu, J, Social support and its consequences." Positive and deficiency values and their implications for support and self-esteem. British Journal of Social Psychology, Vol. 43, pp. 465474, 2004.

[24] Lee,S. \& Kubilius P, The Effects of Services-Learning program on the development of civic attitudes and behaviors among academically talented adolescents. Journal of the Education of the Gifted, Vol. 30, pp. 29-67, 2006.

[25] Radford, M, Emotional Intelligence and education. International Journal of Children's Spirituality, Vol. 8, pp. 255-268, 2003.

[26] Watson, M, Long-term effects of moral/character education in elementary schools in pursuit of mechanism. Journal of Research in Character Education, Vol. 4, pp. 1-18, 2006.

[27] Waluyo, J.Herman, Drama, Teori dan Pengajarannya. Yogyakarta: Hanindita Graha Widya, 2008.

[28] Moore, K.D., Effective instructional strategies: From theory to practice. Thousand Oaks, CA: Sage Publications, 2005.

[29] Kolb, A.Y., and Kolb, D.A., "Learning styles and learning spaces: Enhancing learning in higher education". Journal of Academy of Management \& Education, Vol. 4, pp.193-212, 2005. 
[30] Mainemelis, C., and Ronson, S., "Ideas are born in fields of play: Towards a theory of play and creativity in organizational settings," Research on Organizational Behavior, Vol. 27, pp. 81-131, 2006.

[31] Ahmadi, Rulam, Memahami Metode Penelitian Kualitatif. Malang: Universitas Negeri Malang Press, 2005.

[32] Yin, R.K, Case study research: Design and method, Sage Publication, Newbury Park, CA, 1989.

[33] Stake, R.E, "Case Studies," in Denzin, N.K. and Lincoln, Y.S. (eds.), Strategies of qualitative inquiry. Sage Publications, Thousand Oaks, CA, pp. 86-109, 1998.

[34] Derryberry, P., Wilson, T., Snyder, H., Norman, T., \& Barger, B, Moral Judgment developmental differences between gifted Youth. The Journal of Secondary Gifted Education, XVII, pp. 6-19, 2005.

[35] Price-Mitchell, M, Civic learning at the edge: Transformative stories of highly engaged youth. Doctoral Dissertation, Fielding graduate University, Santa Barbara,CA, 2010.

[36] Muslich, Masnur, KTSP. Pembelajaran Berbasis Kompetensi dan Kontekstual. Jakarta: Bumi Aksara, 2007.

[37] Mulyasa, E, Kurikulum Berbasis Kompetensi, Konsep, karakteristik, dan Implementasi. Bandung: Remaja Rosdakarya, 2003.

[38] Kama, Abdul Hakam, Pengembangan Model Pembudayaan Nilai-Nilai Moral dalam Pendidikan Dasar di Indonesia: Studi Kasus di Sekolah Dasar Negeri Bandungrejosari Kota Malang, Jawa Timur. Jurnal Sosiohumanika, Vol. IV, pp.167-168, 2011.

[39] Merilainen, M, The self-perceived effects of roleplaying hobby on personal development- a survey report. International Journal of RolePlaying, Vol. 3, pp.49-68, 2012.

[40] Srikala, B, \& kumar, K, Empowering adolescents with life skills, education in schools-school mental health program. Does it Work? Indian Journal of Psychiatry, Vol. 52, pp. 344-350, 2010.

[41] Sukmadinata, Nana Syaodih, Metode Penelitian Pendidikan, Bandung: UP dan Rosdakarya, 2008.

[42] Gupta, P. \& Puja, A Study on Moral Judgment ability of pre-adolescent Children (9-11 Year) of public Schools. International Journal of Education and allied Science, Vol. 2, pp.73-86, 2010.

[43] Martin, A., Marsh, H., McLnerney, D., Green, J., \& Dowson, M, Getting along with teachers and parents: The yields of good relations ships for students' achievement motivation and self-esteem. Australian Journal of Guidance and Counseling, Vol. 17, pp.109-125, 2007.

[44] McMillan, James H. \& J.C. Schumacher, Research and Education: A Conceptual Introduction. New York: Addison Wesley Longman, Inc. Fifth Edition, 2011.

[45] Al-Ansari, E, Effect of gender and education on the moral reasoning of Kuwait University Students. Social Behavior and Personality. An International Journal, Vol. 30, pp. 75-82, 2002.

[46] Hasan, SH, Pendidikan Sejarah Untuk Memperkuat Pendidikan Karakter. Jurnal Paramita, Vol. 22 No.1, pp. 83-84, 2012. 